\title{
Grazing behaviour and forage utilization of Nguni, Afrikaner and Simmentaler cattle
}

\author{
EH Osler 1, MJ Linington 1, Y Ford 2, D Swart 2 \\ Irene Animal Production Institute, Private Bag X2, Irene $1675 ; 2$ Roodeplaat Grassland Institute, \\ Private Bag X05, Lynn East 0039, South Africa
}

Cattle indigenous to southern Africa (Nguni and Afrikaner) as well as exotic Simmentaler cattle were studied to compare their ability to maintain condition on protein deficient winter grazing. The study was conducted from March 1993 to March 1994 in sourish mixed bushveld, $30 \mathrm{~km}$ north-east of Pretoria, South Africa. The year was divided into summer forage (good quality), winter forage (poor quality) and forage regrowth (intermediate quality).

Forty five 14-month-old bulls were randomly allocated to 9 camps ; 3 camps per breed and 5 animals of a breed per camp. Animals were weighed, jugular blood sampled for urea analysis while pasture utilization and grazing behaviour were monitored monthly. Five categories of behaviour namely, standing, drinking, lying, moving and grazing (Altmann, 1974, Behaviour, 49, 227), were noted at ten minute intervals over 24-hour periods for seven days in each month. At one meter intervals along 3 permanent randomly located transects per camp, the nearest grass species were identified and classified into utilization classes
(Kruger and Edwards, 1972, Proc Grassland Soc S Afr, 7, 146).

The Nguni's showed less mass loss $(P \leq 0.05)$ and higher plasma urea levels $(P \leq 0.05)$ during winter than the other two breeds. While Simmentalers moved less $(P=0.034)$ than the indigenous breeds, the Afrikaners were the most active ( $P \leq 0.05)$. Al breeds showed a preference $(P \leq 0.05)$ for palatable grass species over unpalatable and intermediate species with Simmentalers selecting less $(P \leq 0.05)$ of the unpalatable grasses. A habit of drinking other cattle's urine was also noted with the Nguni's.

The indigenous breeds both utilized more unpalatable forage species in winter than the exotic breed but, nevertheless, the Nguni maintained condition better than the Afrikaner or Simmentaler. The data suggests that these differences may not be the direct result of grazing behaviour, but indicate differences in forage species selection.

\begin{tabular}{lcccc} 
Parameter & Nguni & Afrikaner & Simmentaler & SEM \\
ADG winter $(\mathrm{g} / \mathrm{d})$ & -0.193 & -0.248 & -0.307 & 0.03 \\
Urea winter $(\mathrm{mg} \%)$ & 13.33 & 10.99 & 7.61 & 0.593 \\
Move regrowth $(\mathrm{h} / \mathrm{d})$ & 0.86 & 0.78 & 0.69 & 0.27 \\
Drink summer $(\mathrm{h} / \mathrm{d})$ & 0.21 & 0.27 & 0.19 & 0.14 \\
Drink winter $(\mathrm{h} / \mathrm{d})$ & 0.044 & 0.117 & 0.087 & 0.14 \\
Lie regrowth $(\mathrm{h} / \mathrm{d})$ & 10.27 & 8.97 & 9.77 & 1.60 \\
Lie winter $(\mathrm{h} / \mathrm{d})$ & 11.70 & 10.19 & 11.49 & 1.61 \\
Lie summer $(\mathrm{h} / \mathrm{d})$ & 10.77 & 10.91 & 11.18 & 1.61 \\
Unpalatable winter $(\%)$ & 5.71 & 6.19 & 4.40 & 1.41 \\
Palatable winter $(\%)$ & 8.59 & 8.96 & 8.95 & 1.41 \\
\hline
\end{tabular}

